The Martin Luther King, Jr., Papers Project is a collective endeavor that depends on the generosity and talent of many people. This comprehensive edition of King's papers builds on the long-term efforts of individuals and institutions involved in assembling and preserving the documentary legacy of King's life. The present volume is the result of the continued commitment of old and new friends who have assisted the Project in large and small ways that sometimes defy adequate description. Suffice it to say that the King Papers Project's effort to document the Montgomery bus boycott was almost as much a collective effort as the movement itself (and required a longer time to complete). The following acknowledgments are a grateful project director's expression of appreciation rather than a definitive apportioning of credit.

\title{
Institutional Support
}

The Project's sponsor, the Martin Luther King, Jr., Center for Nonviolent Social Change, Inc., has undergone substantial changes during recent years that have altered its relationship with the Project. I continue to benefit from the support and advice of the King Center's founding president and former chief executive officer, Mrs. Coretta Scott King. This edition would not have been possible without her determination to preserve the documentary records of her husband's life or her recognition that this project was necessary. Despite pressing official and family obligations, she has devoted many hours to Project matters during the past few years. Her assistants at the King Center-Lynn Cothren, Doris Ford, and especially Delores Harmon-have also been helpful to me.

In April 1994 Mrs. King relinquished her administrative duties at the King Center to her son, Dexter Scott King, who now serves as president and chief executive officer. As head of the King Center, Mr. King has devoted considerable time and energy to the Project, meeting with me on numerous occasions. Even before his assumption of this role, he took on increasing responsibility for the King estate, discussing with me matters of mutual concern regarding the commercial aspects of King's literary property. From the beginning of our relationship I have been aware that he sees the King Center and the King Papers Project in different terms than his mother. Although both Kings recognize the importance of the Project as a means of preserving Martin Luther King, Jr.'s legacy, he has emphasized the importance of reinvigorating that legacy. We share a strong commitment to preserving King's ideas and expanding their influence, especially among young people, in a new era of electronic communication.

My discussions with Mr. King about King estate matters have often involved Phillip Jones, president of Intellectual Properties Management. I have come to appreciate the enthusiasm that he brings to his task of representing and furthering the interests of the King estate. In addition to working with $\mathrm{Mr}$. Jones to resolve issues relating to the estate's proprietary interests, I have secured his sup- 
port for several projects designed to convey King's ideas and our research to a wider popular audience.

Other members of the King Center administration have devoted considerable energy to our affairs. I have appreciated the professionalism and warm support of the Center's chief administrative officer, Johnny Mack, who, in a variety of financial administrative roles, has always supported the Project and worked with me to manage the expenditure of grant funds. The King Center's senior vice president and treasurer, Mrs. Christine King Farris, has likewise continued to offer vital support to the Project. She met with me on several occasions over the last few years to discuss Project issues, and I consulted with her about her own and her family's activities during the Montgomery bus boycott. I appreciate also the help of her assistant, Barbara Williams. Other staff members of the financial office helped to resolve financial matters as well, particularly Isaac Clark, who went out of his way to expedite arrangements for grant expenditures and reimbursements.

Director of Archives Cynthia Lewis is a dedicated professional who has consistently lent her support to the Project. I also wish to thank former members of the King Library and Archives staff Danny Bellinger and Bruce Keys.

The King Papers Project is conducted in association with Stanford University and Emory University and benefits enormously from the scholarly resources and administrative support of both institutions. At Stanford during recent years the Project has been very fortunate to enjoy the continuing support of President Gerhard Casper and Provost Condoleezza Rice. Operating under the auspices of the School of Humanities and Sciences, the Project has also benefited from the counsel and support of its former dean, Ewart Thomas, and its current dean, John Shoven. I initially reported on Project matters to former Associate Dean Albert Camarillo, an old friend and colleague from Stanford's history department; I now report to Vice Provost Ramon Saldívar, who has been equally encouraging. Former Associate Dean of Graduate Studies Cecilia Burciaga offered steady assistance during the time she supervised the Project's grant from the Irvine Foundation, as did Irvine Program Coordinator Daniel Ramirez. Joan Minor, Assistant Dean of Human Resources, provided vital assistance on personnel matters, as did Nancy Padgett, Associate Dean and Director of Finance, who has helped the Project with budgetary concerns. Katherine Key, Edgar Chicas, and Victor Sosa of Sponsored Projects supervised and provided assistance for the Lilly Foundation grant. Stanley Bo Parker, Norman M. Roth, J. Lynn Sinclair, and Charles M. Stewart of Information Technology Systems and Services (ITSS) have provided consistent expertise, guidance, and support for the Project's computer database systems. Stuart K. Snydman, a former student researcher who now works for ITSS, has also been extremely helpful regarding computer networking issues and designed the Project's initial World Wide Web site. Development officers Michael Britt, Evelyn Kelsey, and Henry Organ have assisted the Project's never-ending pursuit of additional funding. Rev. Floyd Thompkins, former Associate Dean of Memorial Chapel, not only was unstinting in his general support for the project but also played the leading role in a theatrical docudrama, Passages of Martin Luther King, produced by the King Papers Project.

At Emory, the King Papers Project office has continued to strengthen its 
tributing Editors Rosemary Hynes and Penny A. Russell. The Project has received crucial support from Emory administrators at every level, including President William M. Chace, Provost Billy E. Frye, Vice President for Arts and Sciences David F. Bright, Dean of the School of Arts and Sciences and Vice President for Research George Jones, Associate Vice President of Graduate Studies Eleanor Main, Associate Dean Alice Benston, Graduate School Business Manager Tom Stitt, and Administrative Assistant Carl Reid. History Department Chair James Roark was consistently helpful to Virginia Shadron as she has expanded the Project's activities at Emory. The following Emory faculty members have served on the Project's informal faculty advisory committee: Delores Aldridge, Rudolph Byrd, Dan T. Carter, Leroy Davis, Robert M. Franklin, Theophus Smith, and Margaret Spencer.

The Project has also relied on its publisher, the University of California Press, particularly Director James Clark and Associate Director Lynne Withey. Other UC Press staff with whom we have enjoyed working include Erika Büky, Kim Darwin, Fran Mitchell, and copyeditor Anne Canright.

As the Project has progressed, the involvement of its Advisory Board in the editorial process has declined but nevertheless remains important. I have deeply appreciated the useful guidance I have received from this extraordinary group of distinguished scholars and former associates of Dr. King, who are listed on the volume's opening pages. In addition to Mrs. King and Mrs. Farris, I wish to acknowledge in particular the productive discussions of Volume III concerns that I have had with several of the board's members. The sage counsel and friendship of John Hope Franklin and Vincent Harding helped me weather some difficult periods during my time as Project Director. David J. Garrow has always been willing to share his documentary resources and exceptional expertise. I would also like to acknowledge the valuable advice I've received from Louis $R$. Harlan, Robert A. Hill, Darlene Clark Hine, Otis Moss, Jr., Preston N. Williams, Harris Wofford, and Andrew J. Young.

\section{Financial Supporters}

The King Papers Project could not have survived without funding from numerous generous and enlightened donors. Major contributors to this volume include the Division of Research and Education Programs of the National Endowment for the Humanities (NEH); Emory University; the James Irvine Foundation; Peter Kovler; Judith L. Lansing; the Lilly Endowment; the National Historical Publications and Records Commission (NHPRC); the Nordson Corporation Foundation; the David and Lucile Packard Foundation; the John T. Rockefeller Foundation; Stanford University; and the H.W. Wilson Foundation. Individuals at these institutions have often demonstrated a concern for the Project far outside the bounds of their professional responsibilities. I acknowledge in particular NEH staff members who have worked with the project, including former Program Officer Douglas M. Arnold, Grants Administrator Steven F. Veneziani, and current Program Officer Daniel P. Jones. NHPRC Executive Director Gerald George, Deputy Executive Director Roger Bruns, Program Director Nancy Sahli, Assistant Program Director Richard Sheldon, and Archivist Donald L. Singer have been generous in their assistance to the Project. In addition, I have appreciated the 
support of Irvine Foundation President Dennis Collins and Lilly Endowment Program Director Jacqui Burton. Carolyn Gibson and Constance Haqq of the Nordson Corporation Foundation were also very helpful.

Since early 1992, many individuals have taken the opportunity to join the Stanford University Associates of the Martin Luther King, Jr., Papers Project, a fundraising support group for our Stanford office. Associates in the Patron category include the Ruth M. Batson Educational Foundation; Diane F. and James A. Geocaris, Jr.; William P. Madar; the San Jose Mercury News; and Elizabeth Traugott.

Donors include Ann Appleman; Keith Archuleta; Big Apple Films; Taylor Branch; Wayne Duckworth; Mary McKinney Edmonds; Ernst and Young, Northern California Division; the First Hebrew Congregation of Oakland, Temple Sinai; George M. Fredrickson; Granite Broadcasting Corporation; Ronne and Donald Hess; L. Tyrone Holt; Benson Kanemoto; Lydia Kennard; KNTV Radio and Television, San Jose; Lockheed Missiles and Space Corporation, Inc.; Leanne MacDougall; the Martin Luther King, Jr., Association of Santa Clara Valley; Woodrow A. and Debra J. Myers, Jr.; Jerry Nightingale; George Ow, Jr.; University National Bank and Trust Co.; the University of Newcastle upon Tyne; and Wyse Technology.

Sustainers and members include Carolyn Barnes; Gracia Bell; Julian Bond; Michael R. and Rosalyn M. Britt; Roger and Ora Clay; Harvey L. and Fannie L. Cole; John A. Dittmer; Richard B. Fields; James and Eva Goodwin; Gloria Guth; Tom Hayden; Virginia M. Henderson; Lisa Hoyos; Gerald Jackson; Michael Kazin; the Links, Inc. (Peninsula Chapter); Doug J. McAdam; Marsha Meinel; Thomas J. Mikelson; Robert S. Moorehead; Henry Organ; Pamela Petty; Beverly P. Ryder; Sun Microsystems, Inc.; Temple Beth El; Bill Walsh; Shelly Weintraub; Rosalind Wolf; and Richard Wylie.

\section{Staff Members}

This volume is the result of a long-term collaboration involving student and postgraduate researchers in which academic credentials counted for less than demonstrated ability and dedication. From its inception, the mission of the King Papers Project has been not only to produce a definitive edition of King's papers but also to provide an opportunity for able and dedicated students to acquire research skills and to increase their understanding of the modern AfricanAmerican freedom struggle. The availability of such learning opportunities has reinforced the project's strong ties to Stanford and Emory. As the project has evolved, a few veteran staff members have provided an essential degree of stability amid the continual turnover of student and professional researchers. The editors listed on the title page have each made vital, and in some instances unanticipated, contributions.

Stewart Burns, the associate editor originally assigned to supervise research on this volume, remained associated with the Project until funding for his position expired in September 1994. Stewart's knowledge of the civil rights movement and his commitment to King's ideals made him an effective mentor for the Stanford students and summer interns assigned to work with him. He personally selected documents for the volume, supervised document transcriptions, and prepared 
has continued to volunteer useful suggestions on the manuscript as it neared completion.

After Stewart's departure, the remaining staff began an intense period of work on the behind-schedule manuscript. A major contributor to this extraordinary effort was Susan Carson, who moved from her position as the Project's librarian and archivist to that of managing editor, coordinating the daily activities of other staff members and many of the student researchers. Having designed the document database, she possessed unparalleled knowledge of the diverse activities associated with the Project, from preparation of grant proposals and document acquisition to cataloging and manuscript preparation.

Editorial Assistant Dana L. H. Powell, whom I recruited upon her graduation from Howard University, worked closely with Stewart before his departure. Her high level of conscientiousness, dedication, and willingness to take on additional responsibilities made it possible for us to complete the volume. During her year and eight months as a staff member, Dana's quick mastery of the necessary documentary editing skills allowed her to make a major contribution both to this volume and to Volume II.

Contributing Editor Peter Holloran has been involved in the Project ever since he joined the staff as a Stanford sophomore in 1985 . After contributing heavily to the first two volumes, Pete has made his remarkable editorial skills available to us on a part-time basis during the past two years. It has been a singular pleasure to work with him and to observe his coming-of-age as a scholar and as a person.

In addition to those acknowledged on the title page, many other staff members made essential contributions to this volume. When Dana returned to Washington, D.C., in the spring of 1995, she was replaced by Katrina Nusum, a Stanford graduate who had previously worked at the Project as a research assistant. Katrina assumed primary responsibility for the final preparation of this volume, coordinating its progress through to publication. She participated in hundreds of editorial discussions and managed to stay on top of thousands of details. I have greatly appreciated her patience and persistence.

Since fall 1995 Assistant Archivist Jodie Medeiros, a former summer intern, has made an important contribution to the volume, supervising student researchers and handling the countless details that are required for a documentary edition. Other staff members who assisted on this volume include former Assistant Archivist Elizabeth Báez, who has continued to assist the project while pursuing medical studies in Atlanta, and research assistants Michelle Walsh, Amy Whitcomb, and Judy Wu.

Former volume editor Ralph E. Luker graciously agreed to return to the Project on a temporary basis during 1995 . His broad and extended experience with the King Papers Project contributed greatly to the editing of this manuscript during its final stages.

Although not directly involved in the research or writing of this volume, other individuals have contributed to its completion. Project Administrator Karl Knapper has handled the daily management of the Project's financial affairs as well as my own scheduling and travel arrangements. I have appreciated the calm and good cheer with which he has carried out a difficult job. Aylin Altan served the Project well during her year as the Project's consultant on fund-raising. Carolyn Barnes volunteered to assist the Project's fund-raising efforts. In addition, the fol- 
lowing assistants have undertaken the difficult and sometimes unrewarding task of bringing order to my office: Temera Carson, Mary Anne M. Morgan, Haleema J. Quraishi, and Heather D. Williams.

\section{Student Researchers: Stanford Office}

The Project has always depended on the skills, dedication, and exceptional talents of Stanford students. These students, working as interns, volunteers, or for academic credit, have contributed enormous energy and enthusiasm. Undergraduate researchers who worked on Volume III or whose work was not acknowledged in previous volumes include Stephanie Baca-Delancey, Sarah Bacon, Prithika Balakrishnan, Denise Barrett, Lily Batchelder, Kristin Beattie, Alaina C. Beverly, Kofi Bruce, Cherie Burgess, Alan Burnce, Kimberly Burton, Alice Chang, Danielle Colding, Lisa Dawe, Daniel P. K. Diffenbaugh, Theo Emery, Alice Feng, Claudine Gay, Emily Haines, Malcolm Hanson, Sanjiv Harpavat, Louis Jackson, Mark Jeter, Lisa Kohn, Julia Lanoff, Kaira Lingo, Annie Luetkemeyer, Michael MacKenzie, Jennifer Marcus, Anthony Marsh, Tasha McNeil, Hope Mohr, Mary Anne Morgan, Olivia Ongpin, Aresa Pecot, Haleema J. Quraishi, Urmila Rajagopal, Matthew Scelza, Carmella Schaecher, Michelle R. Scott, Chloe Sladden, Stephanie Soler, Ryan Tacorda, Wesley Watkins, Heather D. Williams, Nikki Williams, Thomas Earl Williams, Jr., Michael Winnick, and Zachary V. Wright. Graduate students who contributed to the Project's research efforts include Stephanie Brookins, Angela Brown, Bernard Butcher, Leslie Harris, Kevin Mumford, Lennora Redmond, Renee Romano, Tselane Sheppard-Williams, Stuart K. Snydman, and Michael Whamond. Researchers Robert S. Moorehead and William Tucker also provided indispensable assistance in this area. 'Alim J. Beveridge, Ismael Medrano, Marcus Treviño, and Huma Waheed supplied the Project with invaluable computer expertise that helped to maintain our electronic databases and computers. The Project's World Wide Web site has been upgraded and maintained by Michael MacKenzie, Joshua Jacobson, and Carmella Schaecher.

The Project has also benefited from the participation of a number of graduate and undergraduate students from other colleges and universities who were able to work at our Stanford offices through the auspices of an internship funded by the Irvine Foundation. They include Erica Armstrong (University of Pennsylvania), Crystal Feimster (University of North Carolina-Chapel Hill), Matthew Gladue (University of Michigan), Martha Jones (Columbia University), Jodie Medeiros (Clark University), Hasson Perkins (Emory University), Janet Scott (Spelman College), A. Benjamin Spencer (Morehouse College), and E. Stephen Thompson (Morehouse College). Andre Namphy (Harvard University), Jamie N. Saunders (University of California, Berkeley), and Fawzia Topan (University of Newcastle upon Tyne) also participated as volunteers in the Project's research.

\section{Acquisition and Research Assistance}

Volume III, like the volumes that preceded it, would not have been possible without the King-related documents that have been provided to us by numerous individuals and institutions. The King collection at the King Center has been at the 
is the largest existing archive of pre-1962 King materials, has been critically important to this volume. We are especially grateful for the generous assistance of Special Collections Director Howard Gotlieb and Assistant Director Margaret Goostray.

In addition to documents obtained from the King Center and Boston University, we identified more than seventy-five manuscript collections with King-related material important for this volume. Institutions, archives, and libraries that assisted us in locating documents for this volume include the Alabama Department of Archives and History; the American Baptist Historical Society; the Amistad Research Center, Tulane University; the Andover-Harvard Theological Library, Harvard University; the A. Philip Randolph Institute; the Archives of Labor and Urban Affairs, Wayne State University; the Chicago Historical Society; the Dwight D. Eisenhower Library; Fisk University; the University of Georgia; GRM Associates; the John F. Kennedy Library; the Library of Congress; the Linn-Henley Research Library, Birmingham Public Library; the University of Massachusetts, Amherst; the Montgomery County Court House; the Moorland-Spingarn Research Center, Howard University; Morehouse College; the National Archive for Black Women's History; the National Archives Library; the National Broadcasting Company, Inc.; the Presbyterian Department of History; Princeton University; the Bayard Rustin Fund; the Schlesinger Library on the History of Women in America, Radcliffe College; the Schomburg Collection, New York Public Library; the Southern Baptist Convention Historical Commission; the Stanford University Libraries; the State Historical Society of Wisconsin; the Swarthmore College Peace Collection; the Levi Watkins Learning Center, Alabama State University; the Robert W. Woodruff Library Archives and Special Collections, Atlanta University Center; Vanderbilt University; and Yale University.

Dr. King's acquaintances and colleagues have been among the most important sources of King-related documents. Of those whom we were able to contact, many assisted us immeasurably in our research, and some graciously allowed us to make photocopies of the documents in their possession, which until now have not been published. These individuals include T. M. Alexander, Leonard Ballou, Worth Littlejohn Barbour, Jeanne M. Brayboy, Raleigh Bryant, Thomasina Burke, Johnnie R. Carr, Samuel DuBois Cook, Charles C. Diggs, Jr., Ernest C. Dillard, Mary McKinney Edmonds, John England, John D. Erb, Pinkie Smith Franklin, Edgar N. French, F. Beatrice French, Overa B. Glasco, R. J. Glasco, Robert S. Graetz, Julian O. Grayson, Hazel Gregory, W. T. Handy, Jr., Roland E. Haynes, R. W. Hilson, Robert E. Hughes, Homer A. Jack, M. J. Jones, George D. Kelsey, Thomas Kilgore, Jr., Joel Lawrence King, Sr., Gil B. Lloyd, William Robert Miller, Ernest Morgan, Walter G. Muelder, Earl E. Nance, Sr., L. Michelle Odom, H. J. Palmer, John Patterson, Harold E. Pinkston, Sr., Samuel D. Proctor, Maxwell M. Rabb, Thelma Austin Rice, S. Paul Schilling, Vivian C. Stanley, Francis S. Thomas, Charles Walker, Eunice Guy Weston, H. Edward Whitaker, and Harris Wofford.

Individuals who gave permission for publication of the documents of relatives include Ann Muste Baker, Worth Littlejohn Barbour, Sylvia W. Bigelow, Mary E. Britton, Marie Faulkner Brown, Yvonne Shade Clark, Thomas Allen Coleman II, Mildred J. Davis, Madeleine DeWolf, Zera L. Dockery, Elizabeth Johns Drake, Mary McKinney Edmonds, Myrlie Evers-Williams, JoAnne Grant, Hazel Y. Gray, Mrs. J. Raymond Henderson, Eldredge Hiller, R. Louise Hope, Thorsten W. Hor- 
ton, Howard E. Jernagin, Edward K. Kaplan, Margaret Morgan Lawrence, Martha H. Lorraine, Maurice Marie-Sainte, William T. Mason, Jr., Lovelle A. Maxwell, Diane Dickerson Montgomery, Elizabeth Olney, Janet L. S. Brown Page, Charles L. Peck, Helen M. Smiley, Alice Smith, Esther Smith, Vivian C. Stanley, John M. Swomley, Jr., Fran Thomas, Sue Bailey Thurman, Elizabeth Chalmers Todrank, Joan Blanton Tucker, Aminda Wilkins, Aubrey Williams, Jr., and J. B. Wood.

Dexter Avenue King Memorial Baptist Church and Ebenezer Baptist Church have generously made available to us important documents from King's life as pastor of these churches.

The following institutions and individuals assisted the Project's audiovisual acquisitions and research for this volume: AP World Wide Photos; the Archival and Museum Collection, Hampton University; the Bettman Archives; the CBS News Archives; Harvey Dinnerstein; Magnum Photos, Inc.; Burt Silverman; Vivian C. Stanley; Time, Inc.; and Sandra Weiner.

Permissions were obtained with the assistance of Thomas Battle, the MoorlandSpingarn Research Center; Barbara B. Coolidge, Shawmut Bank Connecticut; Wayne Furman, the Norman Thomas Papers, New York Public Library; Norman Hill, the A. Philip Randolph Institute; Beth M. Howse, the Fisk University Library; Karen L. Jefferson, the Moorland-Spingarn Research Center; Wallace Liverance, Jr., Burke and Burke Law Firm; Jeffrey D. Marshall, the Bailey-Howe Memorial Library, University of Vermont; Mary Lou Morell, Shawmut Bank Connecticut; Archie Motley, the Chicago Historical Society; Clifford L. Muse, Jr., the Moorland-Spingarn Research Center; Walter Naegle, the Bayard Rustin Fund; Tim O'Brien, Curtis Brown Ltd.; Mattie A. Robinson, the Worker at Nannie Helen Burroughs School, Inc.; Brian E. Urquhart, the Ford Foundation; Dr. Kenny J. Williams, Department of English, Duke University; and Joseph Wilson, Department of Political Science, Brooklyn College.

Several scholars without official ties to the Project also provided invaluable assistance. These include Taylor Branch; Steven M. Millner, Santa Clara University; J. Mills Thornton III, the University of Michigan; and Joseph Wilson, Brooklyn College.

The following individuals kindly consented to interviews in connection with this volume: Maude L. Ballou, Mary Fair Burks, Harvey Cole, Virginia Foster Durr, and Glenn E. Smiley.

A few individuals have greatly enhanced the work of the Project simply by visiting us and talking about their involvement with King and the civil rights movement. Dorothy Cotton, Myrlie Evers-Williams, Vincent Harding, Jesse Jackson, Cornel West, and Harris Wofford have been among the Project's recent invited guests.

Certainly there are other individuals and organizations that participated in and contributed to the success of the King Papers Project. Failure to mention them simply reflects the limits of my memory rather than of my gratitude.

Clayborne Carson 15JUNE 1996 